\title{
Analysis on Change of Precipitation $p H$ and Chemical Characteristics of Acid Rain in Liaoning Province (2007-2018)
}

\author{
ZHOU DE-PING ${ }^{1,2 *}$, WANG YAN ${ }^{3}$, XIE YAN-BIN ${ }^{1}$, WANG XIAO-YING ${ }^{1}$, \\ WANG YANG-FENG ${ }^{1}$, HONG YE ${ }^{1}$ \\ ${ }^{1}$ Institute of Atmospheric Environment, China Meteorological Administration, Shenyang, 110016, China \\ ${ }^{2}$ Weather Modification Office of Liaoning Province, Shenyang 110016, China \\ ${ }^{3}$ Meteorological Information Center of Liaoning Province, Shenyang, 110016, China
}

\begin{abstract}
Acid rain, as one of the outputs of toxic and harmful chemicals from factories, is a serious environmental problem, especially in China, which has harmful ecological consequences and has a direct impact on vegetation and human health. Based on the data of acid rain observation station of Liaoning Meteorological Bureau from 2007 to 2018, the variation of precipitation $p H$ and the distribution of acid rain in Liaoning Province in the past 12 years were analyzed. The result shows: First, the average $\mathrm{pH}$ value of annual precipitation in Liaoning Province is 5.55, which belongs to weak acid rain area. The frequency of acid rain is $12.56 \%$, and the ratio of acid rain to total precipitation is $15.48 \%$. More than 1/5 of the stations are located in the acid rain prone area, among which Dalian and Dandong are seriously polluted, being close to the grade of acid rain frequent area. Second, from 2007 to 2018, the precipitation pH in Liaoning Province fluctuated and increased year by year, with an average annual increase of $0.077 \mathrm{pH}$, and the pollution of acid rain decreased year by year; especially after 2014, Liaoning Province has exited from weak acid rain area, with its precipitation $\mathrm{pH}$ tending to be neutral year by year. Third, acid rain pollution in Liaoning Province is most serious in winter, followed by autumn and summer; in the first six years (2007-2012), the pollution in February was the most serious, and in the last six years (2013-2018), the pollution in December was the most serious, which was significantly worse than the previous six years. Fourth, more efforts have been made to control air pollution in all parts of the country, and the annual decrease in acid precursor emissions is the fundamental reason for the variation of precipitation $p H$ and the improvement of acid rain pollution in Liaoning Province, while the precipitation $\mathrm{pH}$ and acid rain distribution in Liaoning Province are sensitive to the relevant environmental control measures taken by the state in recent years. However, the change of acid rain pollution reminds us to attach great importance to new pollution components and causes.
\end{abstract}

Keywords: Chemical Characteristics, Precipitation pH, Acid rain frequency, Pollution trend, Affected area

\section{Introduction}

The acidity and alkalinity of atmospheric precipitation are expressed by $\mathrm{pH}$, which is defined as the negative logarithm of hydrogen ion concentration, belong to the dimensionless quantity. Acid rain refers to the atmospheric precipitation with $\mathrm{pH}$ less than 5.60 [1-8]. Because the long-term acid precipitation will have a great adverse impact on ecological environment, building surface and human health, and even affect global changes, acid rain has become one of the three global atmospheric environmental problems in the world, and attracted much attention [9-20].

China has carried out acid rain monitoring and research for more than 40 years. In the early 1990s, China Environmental Protection Administration and China Meteorological Administration established acid rain monitoring websites in various provinces and regions, and joined the East Asia acid deposition monitoring network (EANET) through international cooperation [21, 22]. The spatial distribution of acid rain in China is mainly characterized by more acid rain in the south than in the north, more alkaline precipitation in the northwest, and more acid rain in the urban areas than in the

*email: zhou.dp126@gmail.com,yanqizhou234@163.com 
suburbs [23, 24]. From 1993 to 2007, the scope of acid rain area in China expanded to the north with the increased acidity, and the pollution area of acid rain in general showed an expanding trend [25]; the annual direct and indirect economic losses caused by acid rain and main acid gas reached up to hundreds of billion yuan [26].

In the past decade, the Chinese government and relevant departments have taken a series of targeted measures to reduce pollutant emissions and increase environmental pollution control. Since 2008, pollution emissions in various regions of China have been effectively controlled, and the impact scope and pollution intensity of acid rain have been reduced [27-30]. Based on the data of acid rain station network in Liaoning Province of China Meteorological Bureau, and the ecological environment monitoring data released by the environmental protection department, the spatio-temporal variation of precipitation $p \mathrm{H}$ in Liaoning Province from 2007 to 2018, and its characteristics and trends of acid rain pollution were analyzed in this paper. The purpose of the study is mainly discusses the macro factors affecting the $p \mathrm{H}$ variation in Liaoning Province, in order to provide more effective suggestions for acid rain monitoring, evaluation, prediction and pollution control in Liaoning Province.

\section{Materials and methods}

\subsection{Data Sources}

The data of acid rain from 2007 to 2018 come from the routine observation records of 22 monitoring stations in Liaoning meteorological acid rain station, including precipitation, precipitation $\mathrm{pH}$, conductivity $\mathrm{K}$ value, wind direction, wind speed and weather phenomenon. All the acid rain observation projects are implemented in accordance with the "Operational Specification for Acid Rain Observation" issued by China Meteorological Administration, and the automatic precipitation sampling and analysis are consistent with the national standards and the relevant requirements of the World Meteorological Organization.

The acid rain observation in Liaoning Meteorological Bureau started in 1992, and 22 stations had been built by the beginning of 2007, and then the number of conventional stations had gradually increased to 60 in 2018, whose geographical locations are shown in Figure 1. In order to facilitate trend analysis and comparison for many years, this paper only discusses the records of 22 acid rain stations that have been continuously observed for 12 years.

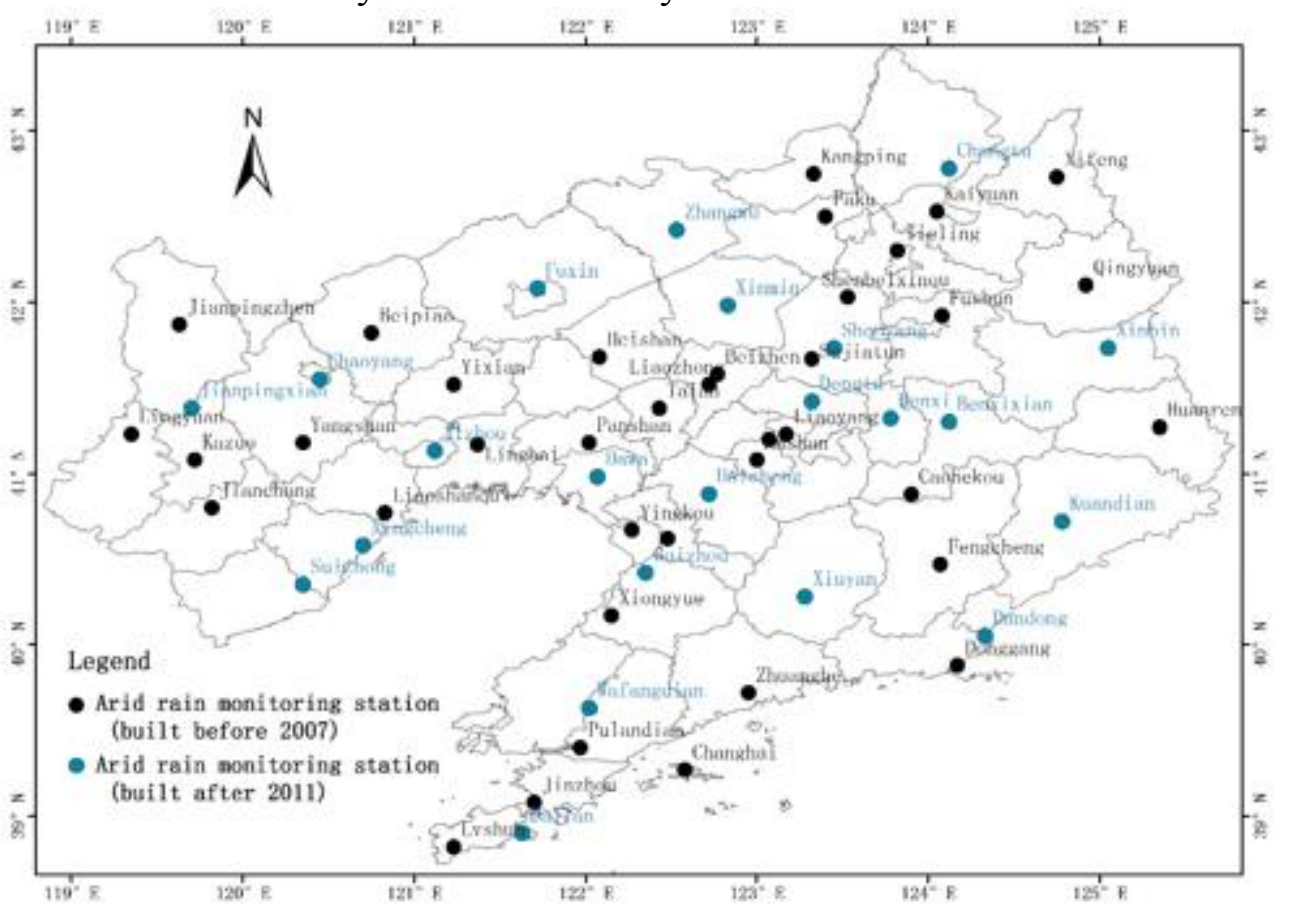

Figure 1. Location map of the meteorological acid rain monitoring stations in Liaoning Province 
In this paper, except for special annotations, the data of air pollutant concentration in Liaoning Province are all from the bulletin of annual environmental conditions published on the website of Liaoning Provincial Department of Ecological Environment[31]; the content and release time of relevant policies and regulations are from the Internet and China government website[32].

\subsection{Statistical method}

According to the Operational Specification for Acid Rain Observation issued by China Meteorological Administration, the weighted average of precipitation is used to calculate the mean value of annual, seasonal and monthly precipitation $p \mathrm{H}$ and conductivity (commonly known as $\mathrm{K}$ value), and the calculation formula is as follows:

$$
\begin{gathered}
\mathrm{pH}=-\lg \left[H^{+}\right]=-\lg \left[\sum_{1}^{n}\left(10^{-p H_{i}} \times R_{i}\right) / \sum_{1}^{n} R_{i}\right] \\
\mathrm{K}=\sum_{1}^{n} K_{i} \times R_{i} / \sum_{1}^{n} R_{i}
\end{gathered}
$$

In formula (1): $p H_{i}=\mathrm{pH}$ of the $\mathrm{i}$-the precipitation; $R_{i}=$ amount of precipitation;

In formula (2): $K_{i}=\mathrm{K}$ value of each precipitation; the conductivity $\mathrm{K}$ value represents the conductivity of atmospheric precipitation, which reflects the cleanliness of atmospheric precipitation, with the common unit of $\mu \mathrm{S} / \mathrm{cm}$.

The $p \mathrm{H}$ value of precipitation shall be conducted with statistics according to the following classification standards: Strong acid rain $(p \mathrm{H}<4.5)$, weak acid rain $(4.5 \leq p \mathrm{H}<5.0)$, less weak acid rain $(5.0 \leq p \mathrm{H}<5.6)$ and non acid rain $(5.6 \leq \mathrm{pH})$; non acid rain includes neutral precipitation $(5.6 \leq p \mathrm{H}<7.0)$ and alkaline precipitation $(7.0 \leq p \mathrm{H})$.

The evaluation of acid rain pollution area is divided by annual (or monthly, quarterly) average precipitation $p \mathrm{H}$ value, including three grades: lighter acid rain area $(5.0 \leq p \mathrm{H}<5.6)$, light acid rain area $(4.5 \leq p \mathrm{H}<5.0)$ and heavy acid rain area $(p \mathrm{H}<4.5)$.

The calculation formula of acid rain frequency in different degrees is as follows:

$$
\mathrm{F}=\mathrm{n} / \mathrm{N} \times 100 \%
$$

where, $\mathrm{F}$ represents the acid rain frequency in corresponding degree, $\mathrm{n}$ and $\mathrm{N}$ respectively represent the number of acid rain in corresponding degree and the total number of precipitation in the calculation period. The acid rain pollution frequency is divided by acid rain frequency, including five grades: occasionally occurred acid rain $(\mathrm{F} \leq 5 \%)$, rarely occurred acid rain $(5 \%<\mathrm{F} \leq 20 \%)$, pronely occurred acid rain $(20 \%<\mathrm{F} \leq 50 \%)$, frequently occurred acid rain $(50 \%<\mathrm{F} \leq 80 \%)$, and highly occurred acid rain $(\mathrm{F}>80 \%)$.

Except for special annotations, the $p \mathrm{H}$ and $\mathrm{K}$ average values of all provinces in the following are the weighted average of rainfall of the measured values in the selected 22 stations.

\subsection{Quality control of observation data}

The $K-p H$ inequality method[33] is used to eliminate the unreasonable data in the statistical analysis of acid rain observation records. From January 2007 to December 2018, there were 23,718 observation records (station-times), among which there were 8,913 station-times without $\mathrm{pH}$ measurement due to the precipitation less than $1.0 \mathrm{~mm}$, and 8 unreasonable samples (accounting for $0.05 \%$ of total samples) were eliminated by $\mathrm{K}-\mathrm{pH}$ inequality method, while 46 data samples without $\mathrm{K}$ value measurement $(0.31 \%$ of total samples) were eliminated, with the valid data samples of 14,687 station-times (about 668 times/station). The total precipitation of 54 samples was $500.9 \mathrm{~mm}(0.29 \%$ of the total precipitation). 


\section{Results and discussions}

\section{1. $p H$ Distribution Probability and Acid Rain Frequency}

In order to investigate the $p \mathrm{H}$ property and grade of precipitation in Liaoning Province from 2007 to 2018 , the probability distribution of daily $p \mathrm{H}$ value of all precipitation in 22 acid rain monitoring stations is calculated. The results show that the 12-year average probability of occurrence for $5.0 \leq p \mathrm{H}$ $<7.5$ is more than $90 \%$, with its annual change increasing year by year, from $76.46 \%$ in 2007 to $96.55 \%$ in 2018 . Among them, the occurrence probability of $6.0 \leq p \mathrm{H}<7.0$ is the most, accounting for about half or even nearly $3 / 4$ of the observation times in each year, followed by the occurrence probability of $5.0 \leq p \mathrm{H}<6.0$ and $7.0 \leq p \mathrm{H}<8.0$, accounting for about $20 \%$. Some statistical results of 22 acid rain observation stations are shown in Table 1.

Table 1. Precipitation $p \mathrm{H}$ statistics and acid rain frequency in various stations in Liaoning Province from 2007 to 2018.

\begin{tabular}{|c|c|c|c|c|c|c|c|c|c|c|}
\hline \multirow{2}{*}{$\begin{array}{c}\text { Acid rain } \\
\text { observatory* }\end{array}$} & \multicolumn{4}{|c|}{$p H$} & \multicolumn{5}{|c|}{ Frequency( 96) } & \multirow{2}{*}{$\begin{array}{c}\text { Frequency } \\
\text { of acid } \\
\text { rain( } \%)\end{array}$} \\
\hline & $\begin{array}{l}F=80 \% \\
\text { interval }\end{array}$ & $\operatorname{Min}$ & $\operatorname{Max}$ & Averoge & $3.0 \leq p H<4.5$ & $4.5 \leq p H=5.0$ & $5.0 \leq p H=5.6$ & $5.6 \leq p H=7.0$ & $\mathrm{pH} \geq 7.0$ & \\
\hline Dalain(DL) & $4.5-6.5$ & 3.21 & 7.74 & 4.86 & 9.16 & 15.37 & 24.87 & 26.42 & 1.56 & 49.40 \\
\hline Dandong(DD) & $4.5-6.5$ & 3.71 & 7.36 & 5.08 & 6.74 & 13.36 & 23.41 & 30.53 & 1.27 & 43.51 \\
\hline Wafangdian(WFD) & $5.0-7.0$ & 3.28 & 7.71 & 5.33 & 3.24 & 7.46 & 20.91 & 44.09 & 1.78 & 31.61 \\
\hline Kuandian(KD) & $5.0-7.0$ & 4.18 & 7.59 & 5.49 & 0.55 & 4.11 & 26.19 & 45.29 & 4.66 & 30.85 \\
\hline Benxixian(BXX) & $5.0-7.5$ & 3.53 & 8.52 & 5.26 & 4.01 & 6.06 & 10.30 & 40.50 & 26.09 & 20.37 \\
\hline Dawa[DW] & $5.6-7.0$ & 4.31 & 8.86 & 5.84 & 0.65 & 1.31 & 5.06 & 67.05 & 7.83 & 7.02 \\
\hline Suizhong(5z) & $5.6-7.0$ & 4.59 & 7.34 & 6.02 & 0.00 & 1.07 & 5.71 & 61.78 & 1.25 & 6.78 \\
\hline Changtu(CT) & $5.6-7.5$ & 3.95 & 9.09 & 5.74 & 0.79 & 1.59 & 7.53 & 42.41 & 29.06 & 9.91 \\
\hline Fuxin(FX) & $5.6-7.5$ & 3.61 & 9.34 & 5.42 & 2.48 & 2.67 & 6.87 & 51.71 & 27 & 12.02 \\
\hline Zhangwu(ZW) & $5.6-7.5$ & 3.70 & 8.85 & 5.62 & 0.36 & 1.60 & 9.22 & 57.8 & 19.32 & 11.18 \\
\hline Shenyang(5Y) & $6.0-7.0$ & 4.72 & 8.30 & 6.14 & 0.00 & 0.67 & 1.62 & 85.33 & 9.14 & 2.29 \\
\hline Xinmin(XM) & $6.0-7.0$ & 5.17 & 8.01 & 6.35 & 0.00 & 0.00 & 0.16 & 96.78 & 1.93 & 0.16 \\
\hline Xingcheng $(\mathrm{XC})$ & $6.0-7.0$ & 3.85 & 7.32 & 5.86 & 0.42 & 3.81 & 2.33 & 85.63 & 0.85 & 6.56 \\
\hline Jinzhou(Jz) & $6.0-7.0$ & 5.19 & 7.79 & 6.57 & 0.00 & 0.00 & 0.36 & 88.89 & 10.2 & 0.36 \\
\hline Benxi(BX) & $6.0-7.5$ & 4.13 & 8.64 & 5.91 & 0.47 & 0.94 & 1.64 & 58.97 & 32.93 & 3.05 \\
\hline Xinbin(XB) & $6.0-7.5$ & 4.03 & 7.83 & 5.84 & 0.64 & 2.77 & 4.79 & 63.83 & 20.85 & 8.20 \\
\hline Dengta(DT) & $6.0-7.5$ & 4.15 & 7.84 & 6.14 & 0.47 & 0.94 & 1.64 & 58.97 & 32.93 & 3.05 \\
\hline Xiuyan $(X Y)$ & $6.0-7.5$ & 3.30 & 8.50 & 5.90 & 0.56 & 0.98 & 1.26 & 71.63 & 24.02 & 2.80 \\
\hline Haicheng(HC) & $6.0-8.0$ & 3.44 & 9.74 & 6.37 & 0.16 & 0.00 & 1.09 & 66.57 & 26.1 & 1.25 \\
\hline Gaizhou(GZ) & $6.0-8.0$ & 4.26 & 8.82 & 5.73 & 0.94 & 1.42 & 3.15 & 56.06 & 32.44 & 5.51 \\
\hline Chaoyang $[\mathrm{CY})$ & $6.0-8.0$ & 4.16 & 8.36 & 6.04 & 0.39 & 0.77 & 6.55 & 47.01 & 40.47 & 7.71 \\
\hline Jianpingxian(JPX) & $6.0-8.0$ & 5.13 & 9.77 & 6.43 & 0.00 & 0.00 & 1.47 & 37.2 & 59.12 & 1.47 \\
\hline
\end{tabular}

*The letters in parentheses are short for station names

As shown in Table 1, the precipitation $p \mathrm{H}$ in the whole province has large fluctuation range, with the minimum $p \mathrm{H}$ value of 3.21, and the maximum $\mathrm{pH}$ value of 9.77 . The stations most seriously affected by acid rain (in order of severity) are DL, DD, WFD, KD, and BXX, with their 12-year average $p \mathrm{H}$ values of 4.86, 5.08, 5.33, 5.49 and 5.26, respectively. And the average annual acid rain frequency of those stations is respectively $49.40,43.51,31.61,30.85$, and $20.37 \%$, all of which belong to acid rain prone areas, with their precipitation frequency with $p \mathrm{H}<5.0$ of $24.53 \%, 20.10,10.70$, 4.66, and $10.07 \%$, respectively. Thus it is no less than that of Beijing, Tianjin and Hebei in North China and parts of South China with serious acid rain pollution $[28,33]$. The nine stations of ZW, FX, $\mathrm{CT}, \mathrm{XB}, \mathrm{DW}, \mathrm{CY}, \mathrm{SZ}, \mathrm{XC}$, and GZ belong to the grade of less acid rain area. In which the $\mathrm{pH}$ value of 
annual precipitation in FX is 5.42, belonging to the grade of light acid rain area; the eight stations of $\mathrm{BX}, \mathrm{DT}, \mathrm{SY}, \mathrm{XY}, \mathrm{JPX}, \mathrm{HC}, \mathrm{JZ}$ and XM with acid rain frequency of $\mathrm{F}<5 \%$ belong to the grade of occasional acid rain area [33-44].

It also can be seen from Table 1 that in the 22 observation stations of the whole province, there are 17 stations that the number of non-acid precipitation days is more than $80 \%$ of the total precipitation days. However, about half of the stations have experienced super acid rain $(p \mathrm{H}<4.0)$, and the 12-year average precipitation $p \mathrm{H}$ is less than 5.60, which is close to $1 / 3$ of the whole province, thus the situation of acid rain pollution in Liaoning Province is still worthy of attention.

\subsection{Inter-annual Variation of $\mathbf{p H}$ And Distribution of Acid Rain}

The provincial average value and provincial annual average of each parameter are calculated by the method of weighted average of precipitation of the 22 stations. The statistical results show that the average precipitation $p \mathrm{H}$ value in 2007-2018 was 5.55, belonging to the grade of light acid rain pollution area; the conductivity $\mathrm{K}$ value was $73.03 \mu \mathrm{S} / \mathrm{cm}$, indicating that there are many pollutants in the atmospheric precipitation in Liaoning Province, resulting in poor air quality [33]. Figure 2 shows the change and trend curves of average $\mathrm{pH}$ and $\mathrm{K}$ value and acid rain frequency in Liaoning Province from 2007 to 2018 .
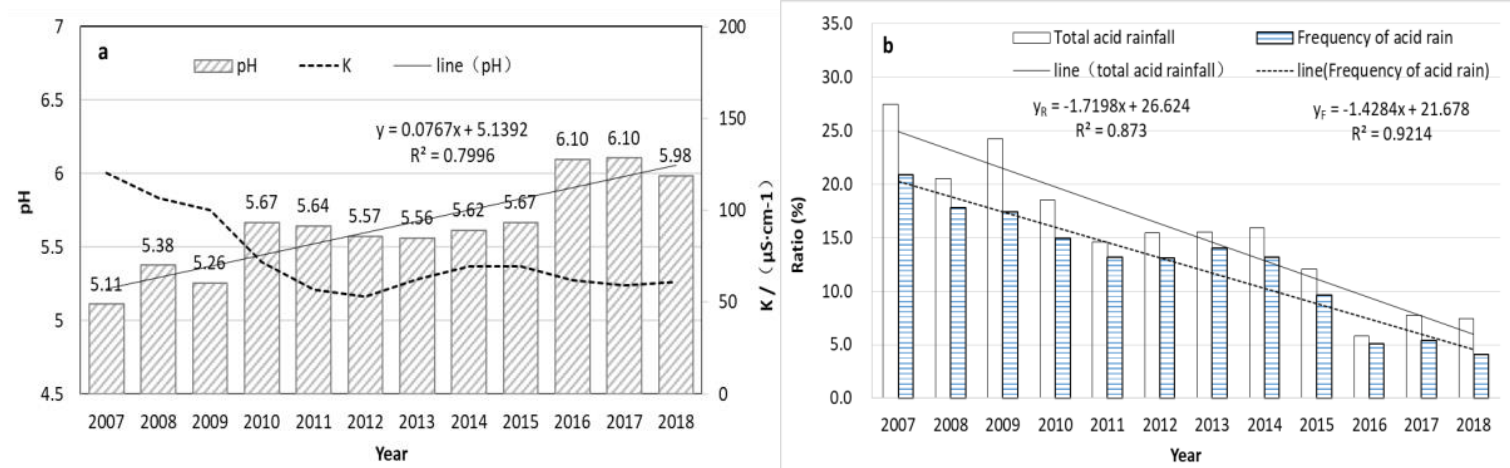

Figure 2. Annual variation of average $\mathrm{pH}$ value(a) and frequency of acid rainfall(b) in the province

As shown in Figure 2(a), the average $p \mathrm{H}$ value of precipitation in the whole province was 5.11 in 2007, followed by 5.26 in 2009, and then 5.38 in 2008, 5.57 in 2012 and 5.56 in 2013. Liaoning Province was in the light acid rain pollution area in the above five years and belonged to the non-acid rain area in the rest years. From the overall trend analysis, the annual change of average precipitation $\mathrm{pH}$ in the whole province shows a linear increasing trend year by year with the annual increase of about $0.077 p \mathrm{H}$, whose linear fitting degree is $\mathrm{R}^{2}=0.7996$. The annual change of $\mathrm{K}$ value is the opposite. In 2007, the maximum $\mathrm{K}$ value was $120.18 \mu \mathrm{S} / \mathrm{cm}$, and then decreased to $53.15 \mu \mathrm{S} / \mathrm{cm}$, but it slightly rose again to $69.76 \mu \mathrm{S} / \mathrm{cm}$ in $2013-2015$, and fluctuated around $60 \mu \mathrm{S} / \mathrm{cm}$ in 2016-2018. In general, the annual K values of precipitation conductivity in Liaoning Province are all greater than 50 $\mu \mathrm{S} / \mathrm{cm}$, indicating the poor precipitation cleanliness [34, 45-47].

It can be seen from Figure 2(b) that in 2007, acid rain accounted for the highest proportion of total rainfall, about $27.49 \%$, followed by $24.20 \%$ in 2009 , with the lowest proportion of $5.83 \%$ in 2016 . From 2007 to 2018, the annual variation of acid rain frequency and acid rain amount in the whole province showed a fluctuating and decreasing trend. And the proportion of acid rain in total rainfall decreased at a rate of $1.72 \%$ per year, with a linear fitting degree of $\mathrm{R}^{2}=0.873$. While the proportion of acid rain frequency decreased at a rate of $1.43 \%$ per year, with a linear fitting degree of $\mathrm{R}^{2}=0.921$.

In order to have a clear understanding of the spatial distribution of precipitation $p \mathrm{H}$ value in Liaoning Province from 2007 to 2018, the spatial distribution of weighted average $p \mathrm{H}$ value of precipitation at 22 stations in each year is drawn by the method of calculating grid interpolation based 
on the weighted average of the distance between longitude and latitude of three adjacent stations, as shown in Figure 3.

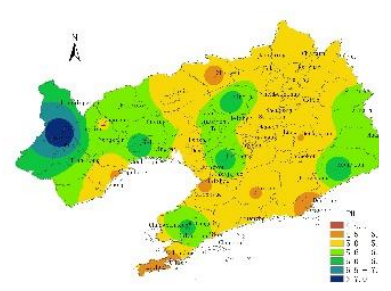

2007

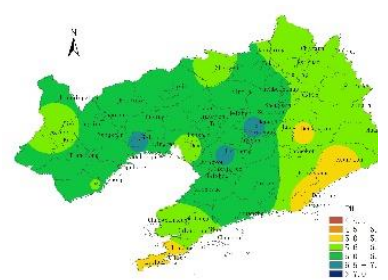

2011

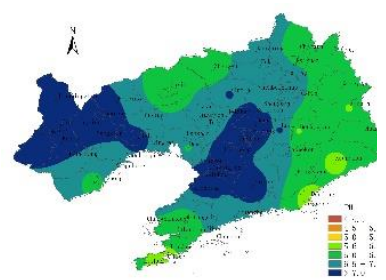

2015

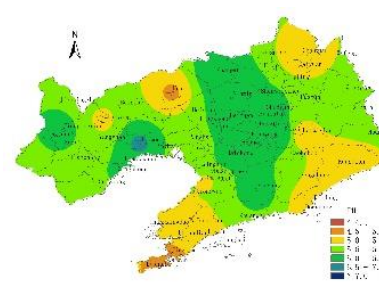

2008

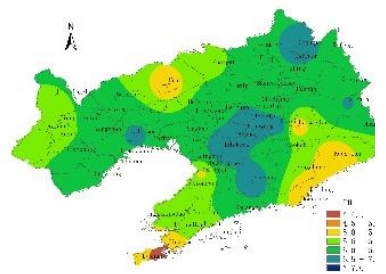

2012

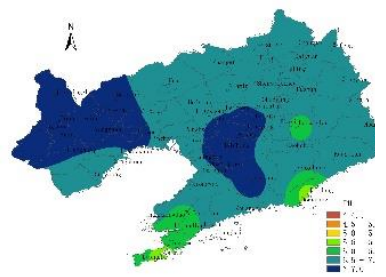

2016

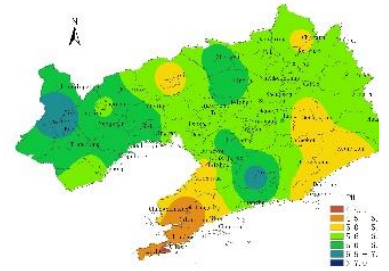

2009

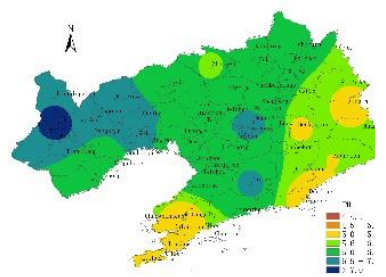

2013

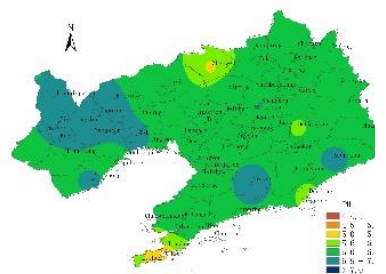

2017

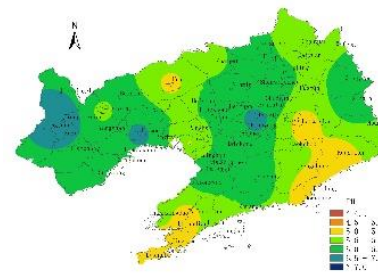

2010

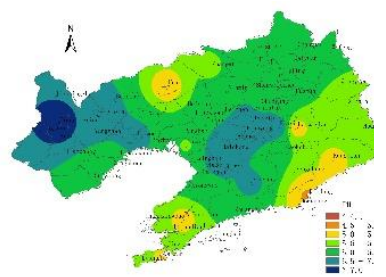

2014

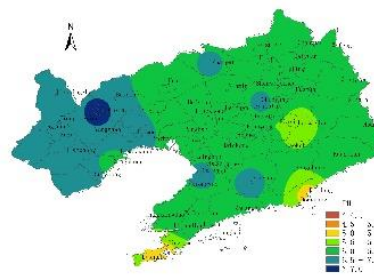

2018

Figure 3. Spatial distribution of annual $p \mathrm{H}$ value of precipitation in Liaoning Province from 2007 to 2018

It can be seen from Figure 3 and Table 1 that the impact range of acid rain in Liaoning Province has a trend of year-on-year fluctuation and reduction. In 2007, acid rain had the largest impact range, with $72.73 \%$ of stations having an average annual precipitation $p \mathrm{H}$ value less than 5.60; among them, $31.82 \%$ of stations have an average annual precipitation $p \mathrm{H}$ value less than 5.0 , reaching the pollution grade of weak acid rain or even strong acid rain. In 2008, the area affected by acid rain in the whole province was reduced to $40.91 \%$ significantly, among which the stations reaching and exceeding the pollution level of weak acid rain are reduced to $9.09 \%$. By 2011, the area affected by acid rain was decreased to $18.18 \%$, and there was no station with annual precipitation $p \mathrm{H}$ reaching and exceeding the pollution grade of weak acid rain. In 2012, the area affected by acid rain had been slightly increasing to 2014, and the stations with annual average precipitation $p \mathrm{H}$ reaching acid rain grade had been kept in the range of 27.27\%; after 2010-2015, the impact scope of acid rain has been further reduced, and the pollution intensity of acid rain has also been reduced significantly.

\subsection{Seasonal Variation of $\mathbf{p H}$ and Characteristics of Acid Rain Pollution}

In order to visually compare the seasonal variation of precipitation $p \mathrm{H}$ value and the characteristics of acid rain pollution in Liaoning Province, the spatial contour distribution of precipitation $p \mathrm{H}$ value and conductivity K value in each season of Liaoning Province from 2007 to 2018 is plotted in Figure 4. 


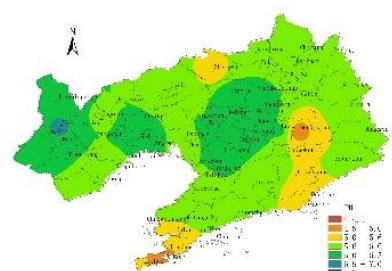

Spring

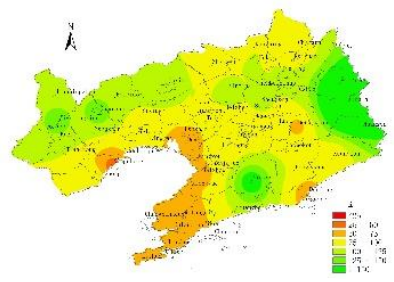

Spring

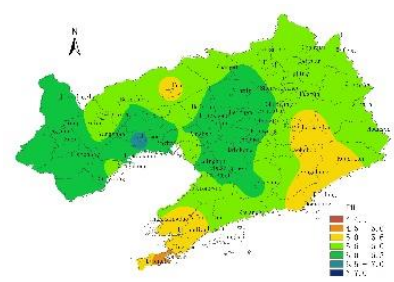

Summer

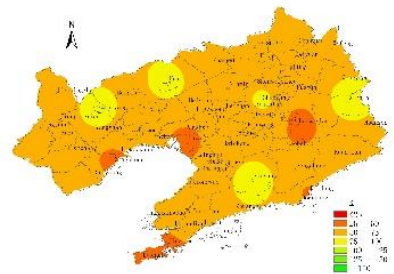

Summer

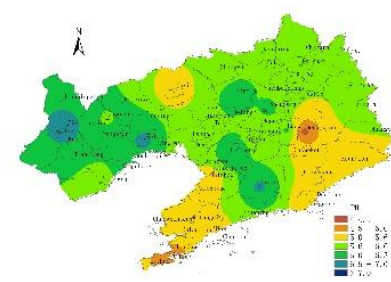

Autumn

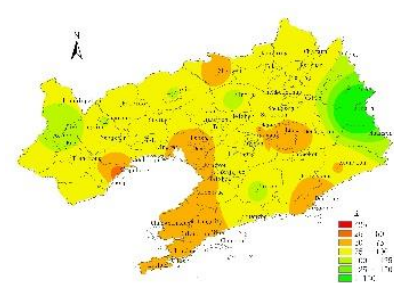

Autumn

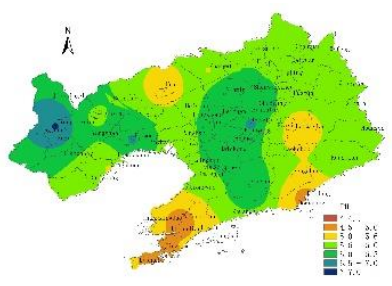

Winter

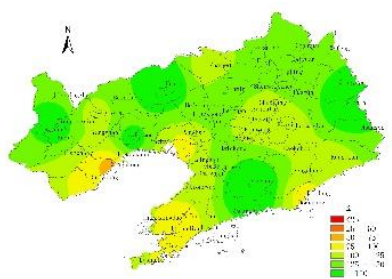

Winter

Figure 4. Seasonal average spatial distribution of precipitation $\mathrm{pH}$ (up) and conductivity $\mathrm{K}$ value

(blow)in Liaoning Province from 2007 to 2018

As shown in Figure 4, the acid rain pollution in Liaoning Province from 2007 to 2018 was the most serious in winter, followed by autumn and the lightest in summer; the precipitation cleanness was the best in summer, followed by autumn and the worst in winter. This result is obviously different from the distribution characteristics of the most serious acid rain pollution in summer of Liaoning Province from 2004 to 2008, which shows that the variation of $p \mathrm{H}$ value in Liaoning Province in recent 10 years is not only reflected in the pollution intensity, but also in the distribution of time and space.

The further analysis on monthly variation of precipitation $p \mathrm{H}$ in Liaoning is helpful to understand the factors affecting the variation and explore the sources of pollution. According to statistics, the monthly change characteristics of acid rain pollution in 2013-2018 are obviously different from that in 2007-2012. In order to facilitate analysis and comparison, 2007-2012 (hereinafter referred to as: the previous 6 years) and 2013-2018 (hereinafter referred to as the following: 6 years) is divided into two stages, and the monthly changes of precipitation $p \mathrm{H}$ and acid rain frequency are counted and plotted in Figure 5 respectively.
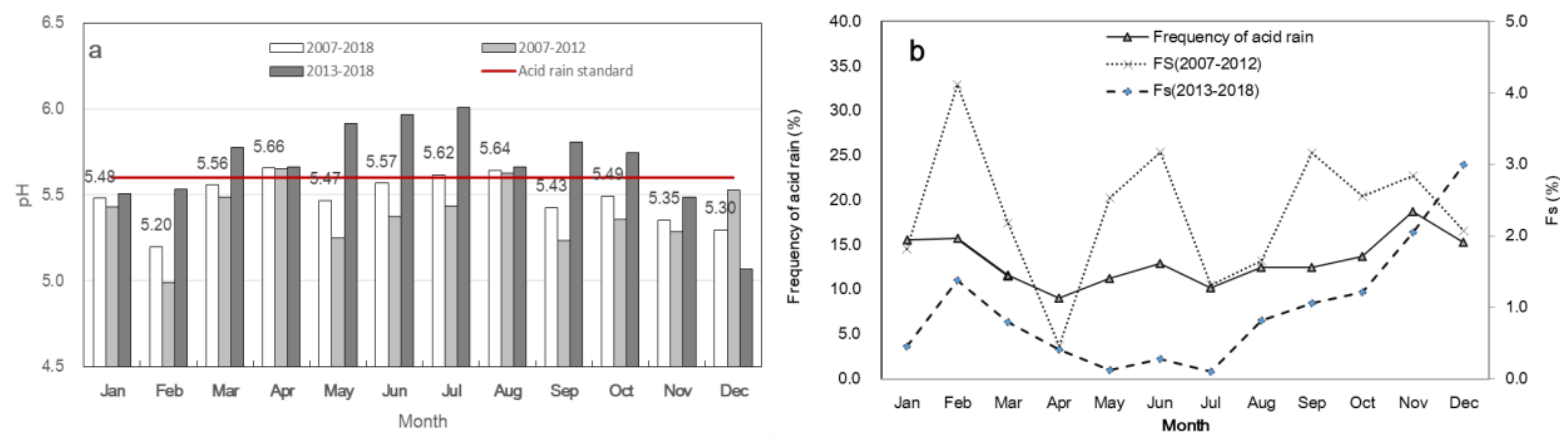

Figure 5. Monthly variation of average $p \mathrm{H}$ value (a) and of acid rain characteristic value $(b)$ in the province

As shown in Figure 5(a), in the first six years, the minimum $p \mathrm{H}$ value appeared in February, followed by September and May; April and August with $p \mathrm{H}$ value more than 5.60 belonged to the nonacid rain, and the rest ten months belonged to the weak acid rain. In the second six years, the minimum $\mathrm{pH}$ value appeared in December, which was significantly lower than the value of the same period in the first six years; the $p \mathrm{H}$ values in the rest eleven months were all greater than the average of the same period in the first six years. The months reaching the grade of weak acid rain are January, February, November and December, which is 6 months less than the first six years. According to the monthly 
variation of acid rain characteristic quantity in the whole province (Figure 5(b)), the number of acid rain days is the most in June, with an annual average of 23.8 station-times, followed by 22.8 stationtimes in August. The months with few acid rain days are January, February, March, December and April, respectively as $4.3,6.3,6.4,6.7$, and 8.5 station-times. However, the month with high frequency of acid rain does not appear in the month with more acid rain days, and the highest frequency of acid rain in November is $18.75 \%$, followed by February and December, which are 15.70 and $15.30 \%$, respectively, while the lowest frequency of acid rain in April is $9.03 \%$.

There are different characteristics in the monthly variation of strong acid rain frequency between the first six years and the second six years. In the first six years, the frequency of strong acid rain showed the multimodal fluctuation, with the highest frequency of $4.12 \%$ in February, followed by $3.17 \%$ in June and 3.16\% in September, and the lowest frequency of $0.47 \%$ in April. In the second six years, the monthly variation of the frequency of strong acid rain basically showed the bimodal arrangement, with the maximum peak value of $2.99 \%$ in December, which increased by 0.91 percentage points compared with the same period of the first six years. The second peak occurred in February with the frequency of $1.38 \%$, which was less than the frequency of strong acid rain in November. In general, the frequency of strong acid rain from January to November in the second six years was lower than that in the first six years, and only the frequency in December was higher than that in the first six years.

\subsection{Variation characteristics of precipitation ion composition}

The $\mathrm{pH}$ value of precipitation depends on the ionic composition of precipitation, not only related to the concentration of acid ions, but also related to the basic ions that can neutralize acid ions. According to the detection data of precipitation ion components of Liaoning Environmental Monitoring and Experiment Center in different years, the change trend of precipitation acidity and composition in Liaoning Province in recent years was analyzed. By revealing the reasons for its changes, we can deepen our understanding of the characteristics of atmospheric precipitation pollution in this area and the impact of human activities, and further analyze and determine the sources of pollutants in precipitation. Tables 2 and 3 give the respective ion concentrations and their proportions of precipitation in different years in Liaoning Province (Table 3 from cological Environment Bulletin of Liaoning Province in 2018).

Table 2. Ions compositions of precipitation at different locations in Liaoning Province ( $\mu \mathrm{eq} / \mathrm{l})$

\begin{tabular}{|c|c|c|c|c|c|c|c|c|c|c|c|c|}
\hline Location & Year & $\mathrm{SO}_{4}{ }^{-2}$ & $\mathrm{NO}_{3}^{-}$ & $\mathrm{Cl}^{-}$ & $\mathbf{F}^{-}$ & $\mathbf{N H}_{4}{ }^{+}$ & $\mathbf{C a}^{+2}$ & $\mathbf{M g}^{+2}$ & $\mathrm{Na}^{+}$ & $\mathbf{K}^{+}$ & {$\left[\mathrm{SO}_{4}{ }^{-2}\right] /\left[\mathrm{NO}_{3}{ }^{-}\right]$} & literature \\
\hline $\begin{array}{l}\text { Liaoning } \\
\text { (13 stations) }\end{array}$ & $\begin{array}{c}1991 \\
-1995\end{array}$ & 509.7 & 56.4 & 83.5 & - & 127.8 & 692.1 & 188.7 & 91.7 & 35.6 & 9.04 & 16 \\
\hline DL & $\begin{array}{c}1991 \\
-1995\end{array}$ & 517.8 & 63.5 & 92.9 & - & 164.5 & 968.1 & 123.8 & 52.6 & 162.7 & 8.15 & 16 \\
\hline DL & 2007 & 212.8 & 62.99 & 72.05 & 16.95 & 127.14 & 139.61 & 32.81 & 41.00 & 8.15 & 3.38 & 17 \\
\hline SY & $\begin{array}{c}1991 \\
-1995\end{array}$ & 984.0 & 102.1 & 132.2 & - & 205.4 & 1369.2 & 486.2 & 64.5 & 130.2 & 9.64 & 16 \\
\hline SY & 2007 & 352.42 & 61.3 & 83.14 & 56.2 & 171.82 & 307.66 & 67.69 & 42.86 & 17.28 & 5.75 & 17 \\
\hline $\mathrm{JZ}$ & 2007 & 97.04 & 21.89 & 39.72 & 0.48 & 3.42 & 37.19 & 13.44 & 36.14 & 1.82 & 4.43 & 18 \\
\hline $\mathrm{JZ}$ & 2013 & 20.30 & 9.31 & 9.86 & 0.60 & 5.00 & 7.66 & 8.92 & 10.12 & 18.48 & 2.18 & 18 \\
\hline $\begin{array}{l}\text { Liaoning } \\
\text { (13 stations) }\end{array}$ & 2007 & 371.16 & 45.11 & 114.68 & 19.63 & 103.90 & 210.05 & 56.28 & 37.47 & 52.30 & 8.23 & 17 \\
\hline $\begin{array}{l}\text { Liaoning } \\
\text { (13 stations) }\end{array}$ & 2009 & $\begin{array}{l}104.72- \\
795.30\end{array}$ & $\begin{array}{l}11.90- \\
244.44\end{array}$ & & & $\begin{array}{l}42.88- \\
281.73\end{array}$ & $\begin{array}{l}41.22- \\
693.41\end{array}$ & $\begin{array}{l}22.41- \\
249.37\end{array}$ & & & 3.9 & 19 \\
\hline $\begin{array}{c}\text { Liaoning } \\
\text { (62 stations) } \\
\text { (mg/L) }\end{array}$ & $\begin{array}{l}2011 \\
-2015\end{array}$ & $\begin{array}{l}11.00- \\
15.21\end{array}$ & $\begin{array}{l}3.58- \\
7.19\end{array}$ & $\begin{array}{l}1.93- \\
3.57\end{array}$ & $\begin{array}{l}0.24- \\
0.36\end{array}$ & $\begin{array}{l}1.50- \\
2.47\end{array}$ & $\begin{array}{l}3.79- \\
5.43\end{array}$ & - & - & - & 3.3 & 20 \\
\hline
\end{tabular}


It can be seen from Table 2 that the main cation of precipitation ions in Liaoning Province is $\mathrm{Ca}^{+2}$, followed by $\mathrm{Mg}^{+2}$ and $\mathrm{NH}_{4}^{+}$; the main anion is $\mathrm{SO}_{4}^{-2}$, followed by $\mathrm{NO}_{3}^{-}$and $\mathrm{Cl}^{-}$. The total ion concentration in precipitation in Liaoning Province is very high, especially in the 1990s and early 2000s. The economic pillars of major cities in Liaoning, known as "China's old industrial base", are dominated by heavy industry. Due to lack of technology and backward plant equipment, the factory has not effectively purified and reduced pollutants before pollutant discharge. Since the early 2010s, the emission of sulfur dioxide and nitrogen oxides has decreased, and the level of pollution has fallen sharply due to the government's effective control measures. In recent years, the ratio of $\mathrm{SO}_{4}{ }^{-2}$ to $\mathrm{NO}_{3}{ }^{-}$ has decreased year by year, indicating that the precipitation pollution has changed from sulfuric acid type to mixed type of sulfuric acid + nitric acid or even sulfuric acid + nitric acid + hydrochloric acid. The average annual concentration order of water-soluble inorganic ions in precipitation in the 1990s is: $\mathrm{Ca}^{+2}>\mathrm{SO}_{4}{ }^{-2}>\mathrm{NH}_{4}{ }^{+}>\mathrm{Mg}^{+2}>\mathrm{Na}^{+}>\mathrm{Cl}^{>}>\mathrm{NO}_{3}>\mathrm{K}^{+}$. The average annual concentration order of water-soluble inorganic ions in precipitation in the 2010s is: $\mathrm{SO}_{4}{ }^{-2}>\mathrm{Ca}^{+2}>\mathrm{Cl}^{-}>\mathrm{NH}_{4}{ }^{+}>\mathrm{Mg}^{+2}>\mathrm{K}^{+}>\mathrm{NO}_{3}>\mathrm{Na}^{+}$.

Table 3. Proportion of ions in precipitation in Liaoning Province( $\%)$.

\begin{tabular}{|c|c|c|c|c|c|c|c|c|c|c|c|c|}
\hline Year & $\mathrm{SO}_{4}^{-2}$ & $\mathrm{NO}_{3}^{-}$ & $\mathrm{Cl}^{-}$ & $\mathbf{F}^{-}$ & $\mathrm{NH}_{4}{ }^{+}$ & $\mathrm{Ca}^{+2}$ & $\mathrm{Mg}^{+2}$ & $\mathbf{N a}^{+}$ & $\mathbf{K}^{+}$ & ¿Cation & EAnion & literature \\
\hline 2009 & 30.8 & 7.9 & 6.6 & 1.8 & 13.7 & 23.8 & 8.1 & 5.5 & 1.8 & 52.9 & 47.1 & 19 \\
\hline 2011-2015 & 29.4 & 8.8 & & 1.6 & 11.1 & 26.5 & & & 2.4 & & & 20 \\
\hline 2018 & 21.4 & 6.7 & 9.3 & 1.7 & 12.3 & 30.8 & 8.8 & 7.0 & 2.0 & 60.9 & 39.1 & \\
\hline $\begin{array}{l}\text { Range of } \\
\text { change( } \%)\end{array}$ & $\begin{array}{c}- \\
30.52\end{array}$ & $\begin{array}{c}- \\
15.19\end{array}$ & 40.91 & $\begin{array}{c}- \\
5.56\end{array}$ & $\begin{array}{c}- \\
10.22\end{array}$ & 29.41 & 8.64 & 27.27 & 11.11 & 15.12 & -16.99 & \\
\hline
\end{tabular}

Compared with the difference in the proportions of major ion components in the precipitation in 2018 and 2009, it is not difficult to find that the proportions of $\mathrm{SO}_{4}{ }^{2-}, \mathrm{NO}_{3}{ }^{-}$and $\mathrm{F}^{-}$in the anions have been reduced in varying degrees, while the proportion of $\mathrm{Cl}^{-}$has been significantly increased. At the same time, compared with the proportion variations of $\mathrm{Na}^{+}, \mathrm{Mg}^{2+}$ and $\mathrm{K}^{+}$as the cation of crustal elements, the total increase of $\mathrm{Na}^{+}$and $\mathrm{K}^{+}$is equivalent to the increase of $\mathrm{Cl}^{-}$. In the free atmosphere, sodium (potassium) ions and chloride ions can combine to form $\mathrm{NaCl}(\mathrm{KCl})$, that is, $\mathrm{Na}^{+}+\mathrm{Cl}^{-} \rightarrow \mathrm{NaCl}$ $\left(\mathrm{K}^{+}+\mathrm{Cl}^{-} \rightarrow \mathrm{KCl}\right)$. The main components of sea salt are $\mathrm{NaCl}$ and $\mathrm{KCl}$, which It can be inferred that the influence of sea salt composition on atmospheric precipitation in Liaoning Province has increased significantly in recent years. There are also $\mathrm{Ca}^{+2}+2 \mathrm{Cl}^{-} \rightarrow \mathrm{CaCl}_{2}$ and $\mathrm{Mg}^{+2}+2 \mathrm{Cl}^{-} \rightarrow \mathrm{MgCl}_{2}$. Thinking further, we will ask a question. Why is Shenyang, an inland city far from the ocean, the chloride ion content of its precipitation higher than Dalian, a coastal city? In fact, $\mathrm{CaCl}_{2}+\mathrm{MgCl}_{2}+\mathrm{KCl}$ is the main component of the snow remover. From here, we think of the situation in which snow removal agents are often used by people in Liaoning during the winter.

Although snow trucks have been used to remove snow in large urban streets in recent years, relatively low-cost snow removers are still used in small areas and economically backward areas. Reflected in atmospheric precipitation shows that in inland cities like Shenyang, sea salt has gradually become the main ionic component. $\mathrm{KCl}$ is the main component of the snow remover, so it is associated with the use of snow removers by people in Liaoning during the winter snowfall. Although in recent years, snow trucks have been used to remove snow in large urban streets, but because of cost inexpensive relatively, snow removal agent is still used in some small places and economically backward regions. The ensuing phenomenon will appear in the atmospheric precipitation of inland cities, and the composition of sea salt ions is higher than that of coastal cities. Of course, the final conclusion needs further observation, analysis and verification [48-58].

The causes for the variation of precipitation $p \mathrm{H}$ are very complex, including the effects of atmospheric composition, particulate matter and meteorological factors. On source investigation, the influence of the concentration of sulfur dioxide and nitrogen oxides on the $\mathrm{pH}$ value is the basic reason for the formation of acid rain. The annual and monthly variations of air pollutant concentration in Liaoning Province in recent years are shown in Figure 6. 

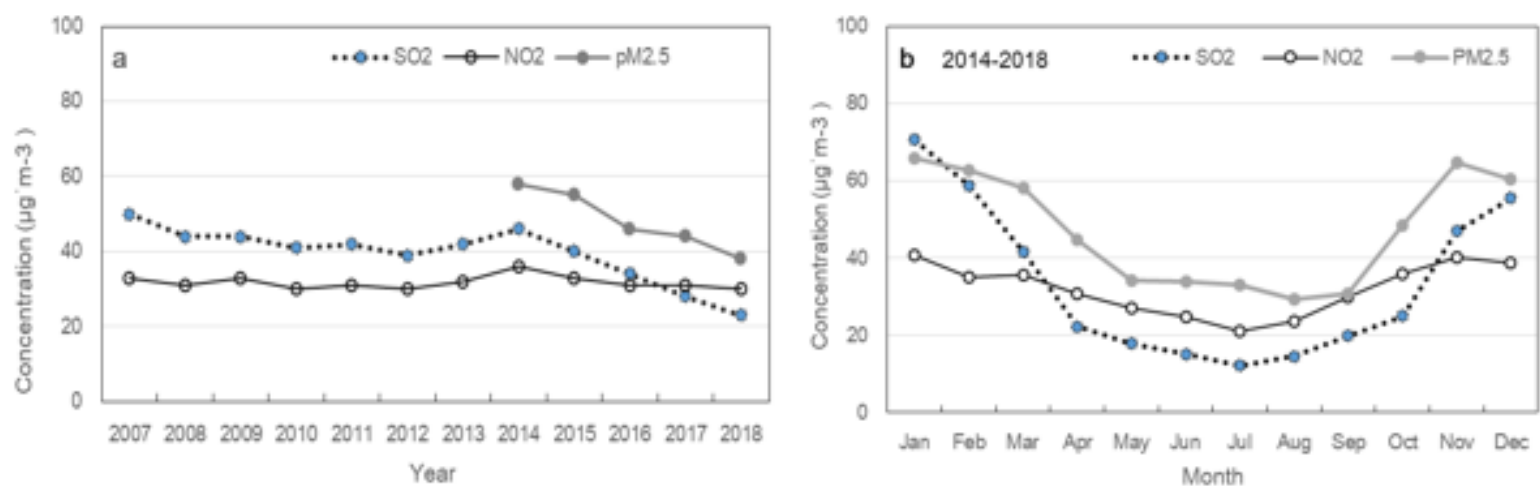

Figure 6. Annual changes(a) and monthly changes from 2014 to 2018 (b) of atmospheric pollutant concentrations in Liaoning Province

As shown in Figure 6(a), after 2014, the $\mathrm{SO}_{2}$ and $\mathrm{NO}_{2}$ concentrations of the acid rain precursors in the atmosphere of Liaoning Province decreased in varying degrees, especially $\mathrm{SO}_{2}$ and $\mathrm{PM}_{2.5}$ decreased significantly. However, $\mathrm{NO}_{2}$ concentration has exceeded $\mathrm{SO}_{2}$ concentration in the last two years (2017 and 2018), which was contrary to the state in the past ten years that $\mathrm{NO}_{2}$ concentration was always lower than $\mathrm{SO}_{2}$ concentration. The monthly variations of the concentrations of various pollutants in Liaoning Province from 2014 to 2018 are shown in Figure 6(b). It indicates that the difference between the heating season (January to March and November to December) and non heating season (April to October) is very obvious, and the $\mathrm{SO}_{2}$ concentration in the heating season is 2-4 times higher than that in the non-heating season, and significantly higher than the $\mathrm{NO}_{2}$ concentration in the same period. The $\mathrm{SO}_{2}$ concentration in the non-heating season is significantly lower than the $\mathrm{NO}_{2}$ concentration.

It can be seen from Figure 6(a) and Figure 2(a) that in recent 12 years, the annual variation of $\mathrm{SO}_{2}$ and $\mathrm{NO}_{2}$ concentrations in Liaoning Province has been reverse consistent with the annual variation trend of precipitation $p \mathrm{H}$ value. The concentrations of $\mathrm{SO}_{2}$ and $\mathrm{NO}_{2}$ are generally decreasing year by year, while the variation trend of $p \mathrm{H}$ value is increasing year by year. However, the variation of precipitation $p \mathrm{H}$ in Liaoning Province is not only affected by local pollution sources, but also by some external sources, so there is no fully synchronous correlation in its variation ranges. By further exploring the detailed characteristics of the inter-annual variation of precipitation $p \mathrm{H}$ in Figure 2(a), it is found that each year with a large variation range of $p \mathrm{H}$ value is closely related to the time nodes for implementing the major national initiatives in atmospheric environmental governance in recent years [59-61].

First, the success of Beijing Olympic Games in 2008 had greatly promoted the comprehensive treatment of environmental pollution by the government and relevant departments. Then with the obvious improvement of national air quality, the annual average $p \mathrm{H}$ value of precipitation in Liaoning Province in 2008 increased by 0.27 than that in 2007, which was 3.5 times of annual average increment. In 2010, the average $p \mathrm{H}$ value of precipitation in Liaoning Province increased by 0.41 , which was 4.3 times higher than that in 2009 , and the pollution intensity of acid rain in this year was reduced significantly, thus Liaoning Province had changed from the lighter acid rain area to the nonacid rain area. The administrative measures closely related to this change are as follows. The "key points of national pollution prevention and control in 2009-2010" and the "guidance on promoting joint prevention and control of air pollution to improve regional air quality" respectively launched in March 2009 and May 2010 by the Ministry of Environment Protection [60-68].

Further strengthen the prevention and control of key pollutants, including the measures of strengthening the total sulfur dioxide control system and strengthening the NOx pollution reduction. From 2010 to 2015, the average $p \mathrm{H}$ value of precipitation in Liaoning Province remained stable at 5.60. Since May 2015, the state has launched a series of measures such as the "overall plan for the reform of ecological civilization system" and the "pilot plan for the reform of ecological environment 
damage compensation system". Then Liaoning Province, like the whole country, has carried out key projects such as blue sky and clear water, with the focus on solving outstanding environmental problems, thus it makes the environmental quality in 2016 show the obvious effect of periodic improvement again. The average $p \mathrm{H}$ value of precipitation in Liaoning Province in 2016 was 0.43 higher than that in 2015, which was 4.6 times more than the annual average increment. After 2016, the frequency of acid rain pollution in Liaoning Province decreased year by year to less than $5.0 \%$ in 2018, thus making Liaoning Province change from the acid rain prone area maintained for more than 10 years (2007-2017) to the acid rain occasional area. Moreover, the concentration of distribution probability of precipitation $\mathrm{pH}$ in Liaoning Province is higher, and in 2016, more than $3 / 4$ of precipitation was in the neutral level $(5.6 \leq p \mathrm{H}<7.0)$.

\section{Conclusions}

(I) In 2007-2018, more than 90\% of the precipitation $p \mathrm{H}$ in Liaoning Province were between 5.07.5, and acid rain appeared at 22 stations in varying degrees, especially in the South and southeast of Liaoning Province, where the acid rain pollution was the most serious, and Dalian and Dandong continued to maintain a stable status of acid rain area.

(II) Generally speaking, the lowest $\mathrm{pH}$ value in Liaoning Province is 5.11 in 2007, with the most serious acid rain pollution. After 2008, it has been reduced year by year, and Liaoning Province has changed from the acid rain prone area in 2007 to the acid rain rare area in 2008-2017, and then become an acid rain occasional area in 2018. Which shows that the measures taken by the Chinese government and relevant departments have played a significant role in reducing pollutant emissions and strengthening environmental pollution control.

(III) The acid rain pollution in Liaoning Province is the most serious in winter, followed by autumn and summer, which is caused by the high concentration of $\mathrm{SO}_{2}$ emission due to the coal combustion in heating season. The monthly distribution of $p \mathrm{H}$ value was the smallest in February of the first six years (2007-2012). The precipitation acidity in February of the six years after 2013 was significantly improved, which may be related to the prohibition of fireworks and firecrackers during the Spring Festival, but the acid rain pollution in December was significantly worse than that in the first six years, and the cause needs further study.

(IV) The concentration of various ions in atmospheric precipitation in Liaoning Province has been significantly lower than in the 1990s, but the overall content is still at a relatively high level, and the cleanliness of atmospheric precipitation in Liaoning Province still needs to be further improved.

(V) Since 2014, the obvious decrease of $\mathrm{SO}_{2}$ emission concentration in Liaoning Province has been the main reason for the increase of precipitation $\mathrm{pH}$ and the decrease of acid rain. However, more attention should be paid to the significant increase of $\mathrm{Cl}^{-}$in precipitation.

Acknowledgements: his work was supported by the National Key R\&D Program of China (Grant No. 2018YFC1507900), Chinese National Natural Science Foundation (41440036) and Chinese National Natural Science Foundation (41505120).

\section{References}

1.SINGH, A., AGRAWAL, M., Acid rain and its ecological consequences. J. Environ. Biol., 29(1), 2008, 15-24.

2.SUN, J., HU, H., LI, Y., WANG, L., ZHOU, Q., HUANG, X., Effects and mechanism of acid rain on plant chloroplast ATP synthase. Environ. Sci. Pollut. Res., 23, 2016, 18296-18306.

3.GORHAM, E., Acid deposition and its ecological effects: A brief history of research. Environ. Sci. Policy., 1, 1998, 153-166.

4.BURNS, D. A., AHERNE, J., GAY, D. A., LEHMANN, C. M., Acid rain and its environmental effects: recent scientific advances. Atmosphere. Environ., 146, 2016,1-4. 
5.CAO, Y., LI, Y., ZHANG, G., JERMSITTIPARSERT, K., NASSERI, M., An efficient terminal voltage control for PEMFC based on an improved version of whale optimization algorithm. Energy Reports, 6, 2020, 530-542.

6.CAO, Y., WANG, Q., CHENG, W., NOJAVAN, S., JERMSITTIPARSERT, K., Risk-constrained optimal operation of fuel cell/photovoltaic/battery/grid hybrid energy system using downside risk constraints method. Int. J. Hydrogen Energy., 2020, 14108-14118.

7.CAO, Y., WANG, Q., FAN, Q., NOJAVAN, S., JERMSITTIPARSERT, K., Risk-constrained stochastic power procurement of storage-based large electricity consumer. J. Energ. Stor., 28, 2020, 101183.

8.LIU, Y. X., YANG, C. N., SUN, Q. D., WU, S. Y., LIN, S. S., CHOU, Y. S., Enhanced embedding capacity for the SMSD-based data-hiding method. Signal Processing: Image Communication, 78, 2019, 216-222.

9.QUAN, Q., HAO, Z., XIFENG, H., JINGCHUN, L., Research on water temperature prediction based on improved support vector regression. Neur. Comput. App., 2020, 1-10.

10.WANG, H., ZHONG, H., BO, G., Existing forms and changes of nitrogen inside of horizontal subsurface constructed wetlands. Environ. Sci. Poll. Res., 25(1), 2018, 771-781.

11.WANG, H., AN, X., ZHANG, Z., Effect of advanced treatment on ammonia nitrogen contained in secondary effluent from wastewater treatment plant. Fresenius. Environ. Bull., 27(4), 2018, $2043-$ 2050.

12.KERESZTESI, A., SANDOR, P., GHITA, G., DUMITRU, F.D., MONCEA, M.A., OZUNU, A., SZEP, R., Ammonium Neutralization Effect on Rainwater Chemistry in the Basins of the Eastern Carpathians - Romania, Rev. Chim., 69(1), 2018, 57-63.

13.IORDACHE, A., WOINAROSCHY, A., Drinking Water Quality Risk Management. Risk Analysis of Nitrogen Groundwater Contamination Using Analytica Software, Rev. Chim., 70(11), 2019, 39713976.

14.LIU, Z., FENG, J., LIU, B., Pricing and service level decisions under a sharing product and consumers' variety-seeking behavior. Sustainability, 11(24), 2019, 6951.

15.WANG, M., ZHANG, D., CHENG, Y., TAN, S. K., Assessing performance of porous pavements and bioretention cells for stormwater management in response to probable climatic changes. $J$. Environ. Manage., 243, 2019, 157-167.

16.LIU, Z., FENG, J., WANG, J., Resource-Constrained Innovation Method for Sustainability: Application of Morphological Analysis and TRIZ Inventive Principles. Sustainability, 12(3), 2020, 917-939.

17.GU, F., GUO, J., ZHANG, W., SUMMERS, P. A., HALL, P., From waste plastics to industrial raw materials: A life cycle assessment of mechanical plastic recycling practice based on a real-world case study. Sci. Total. Environ., 601, 2017, 1192-1207.

18.HAIBIN, L. ZHENLING, L., Recycling utilization patterns of coal mining waste in China. Resour. Conserv. Recycle., 54(12), 2010, 1331-1340.

19.WANG, H., WANG, J., LU, H., BO, G., ZHANG, X., CAO, Y., LIU, L., ZHANG, J., ZHANG, W., Analysis of coating electrode characteristics in the process of removing pollutants from wastewater. Fresenius. Environ. Bull., 29(2), 2020, 715-721.

20.CHENG, Y., SONG, Z., JIN, J., WANG, J., WANG, T., Experimental study on stress wave attenuation and energy dissipation of sandstone under full deformation condition. Arab. J. Geosci., 12(23), 2019, 736-749.

21.WEN-XING, W., Study on the cause of acid rain in China. China. Environ. Sci., 14(5), 1994, $323-$ 329.

22.DING, G. A., XU, X. B., WANG, S. F., YU, X. L., CHENG, H. B., Database from the acid rain network of China Meteorological administration and its preliminary analyses. J. Appl. Meteorol. Clim., 15, 2004, 85-94. 
23.PING, L., FEI, X., JIAYONG, P., YIPING, C., HUAMING, P., SHAOHUA, C., Discuss on Present Situation and Countermeasures for Acid Rain Prevention and Control in China. Environ. Sci. Manage., 12(36), 2011, 30-35.

24.ZHANG, X., CHAI, F., WANG, S., SUN, X., HAN, M., Research progress of acid precipitation in China. Res. Environ. Sci., 23(5), 2010, 527-532.

25.QING, H., YAN-XIA, Z., An analysis on characteristics of regional acid rain over China in 2007. Adv. Clime. Change. Res., 5(1), 2009, 7-11.

26.JIAN-FEI, D., TIAN-TAO, C., JIAN-LI, M., The climatic characteristics and formation of acid rain in Shanghai. Trans. Atmos. Sci., 38(1), 2015, 137-143.

27.GU, F., GUO, J., YAO, X., SUMMERS, P. A., WIDIJATMOKO, S. D., HALL, P., An investigation of the current status of recycling spent lithium-ion batteries from consumer electronics in China. J. Clean. Prod., 161, 2017, 765-780.

28.WANG, M., WEIWEI, L., WANG, K., FANG, S., CENTER, W. R. C., Analysis of variation characteristics of acid rain in Wuhan and its impact factors. Meteor. Mon., 45(2), 2019, 282-289.

29.GUO, J., ZHANG, X., GU, F., ZHANG, H., FAN, Y., Does air pollution stimulate electric vehicle sales? Empirical evidence from twenty major cities in China. J. Clean. Prod., 249, 2020, 119372.

30.LEI, Z., GAO, H., CHANG, X., ZHANG, L., WEN, X., WANG, Y., An application of green surfactant synergistically metal supported cordierite catalyst in denitration of Selective Catalytic Oxidation. J. Clean. Prod., 249, 2020, 119307.

31.***Liaoning Provincial Department of Ecological Environment. Available online: http://sthj.ln.gov.cn/ (accessed on 2507 2019)

32.***China government website. Available online: http://www.gov.cn / (accessed on 1509 2019)

33.JIE, T., XIAO-FANG, J., HONG-BING, C., Improvement of Blind Simple Inter Comparison Study of Acid Rain Monitoring Network. Meteoro. Monthly., 44(12), 2018, 1618-1627.

34.WEI, X., CHUAN-BO, L., YONG-MIN, J., Analysis of Chemical Components of Precipitation in Liaoning Province. Environ. Protec. Sci., 3(24), 1998, 13-15.

35.WANG, P., LI, J. B., BAI, F. W., LIU, D. Y., XU, C., ZHAO, L., WANG, Z. F., Experimental and theoretical evaluation on the thermal performance of a windowed volumetric solar receiver. Energy, 119, 2017, 652-661.

36.ZHU, B., ZHOU, X., LIU, X., WANG, H., HE, K., WANG, P., Exploring the risk spillover effects among China's pilot carbon markets: A regular vine copula-CoES approach. J. Clean. Prod., 242, 2020, 118455.

37.LIU, X., ZHOU, X., ZHU, B., HE, K., WANG, P., Measuring the maturity of carbon market in China: an entropy-based TOPSIS approach. J. clean. Prod., 229(1), 2019, 94-103.

38.ZHU, B., YE, S., JIANG, M., WANG, P., WU, Z., XIE, R., WEI, Y. M., Achieving the carbon intensity target of China: A least squares support vector machine with mixture kernel function approach. Appl. Energy., 233, 2019, 196-207.

39.ZHU, B., SU, B., LI, Y., Input-output and structural decomposition analysis of India's carbon emissions and intensity, 2007/08-2013/14. App. Energ., 230, 2018, 1545-1556.

40.ZHANG, T., WU, X., SHAHEEN, S. M., ZHAO, Q., LIU, X., RINKLEBE, J., REN, H., Ammonium nitrogen recovery from digestate by hydrothermal pretreatment followed by activated hydrochar sorption. Chem. Eng. J., 379, 2020, 122254.

41.GU, F., MA, B., GUO, J., SUMMERS, P. A., HALL, P., Internet of things and Big Data as potential solutions to the problems in waste electrical and electronic equipment management: An exploratory study. Waste. Manage., 68, 2017, 434-448.

42.JI, Q., GUO, J. F., Oil price volatility and oil-related events: An Internet concern study perspective. Appl. Energy., 137, 2015, 256-264.

43.WANG, Y., CAO, L., HU, P., LI, B., LI, Y., Model establishment and performance evaluation of a modified regenerative system for a $660 \mathrm{mw}$ supercritical unit running at the IPT-setting mode. Energy, 179, 2019, 890-915. 
44.WANG, G., WANG, F., SHEN, F., JIANG, T., CHEN, Z., HU, P., Experimental and optical performances of a solar CPV device using a linear Fresnel reflector concentrator. Renewable Energy, 146, 2020, 2351-2361.

45.BIAO, Z., Analysis on the Change Trend of Acid and Pollution in Liaoning Province during the 12th Five-Year Plan. Agri. Technol., 13(38), 2018, 149-151.

46.SHI, C. E., DENG, X. L., WU, B. W., HONG, J., ZHANG, S., YANG, Y. J., Characteristics of Precipitation pH and Conductivity at Mt. Huang. Environ. Sci., 34(5), 2013, 1964-1972.

47.MIN, D., Liaoning province atmospheric wet deposition and chemical characteristics analysis. $J$. Environ. Protect. Sci., 38 (3), 2012, 29-33.

48.CHEN, H., HUANG, L., YANG, L., CHEN, Y., HUANG, J., Model-based method with nonlinear ultrasonic system identification for mechanical structural health assessment. Trans. Emerge. Telecommun. Technol., 2020.

49.ZHU, B., PANG, R., CHEVALLIER, J., WEI, Y. M., VO, D. T., Including intangible costs into the cost-of-illness approach: a method refinement illustrated based on the PM 2.5 economic burden in China. Eur. J. Health. Econ., 20(4), 2019, 501-511.

50.ZHU, B., YE, S., HAN, D., WANG, P., HE, K., WEI, Y. M., XIE, R., A multiscale analysis for carbon price drivers. Energy. Econ., 78, 2019, 202-216.

51.JIANG, M., ZHU, B., CHEVALlIER, J., XIE, R., Allocating provincial CO 2 quotas for the Chinese national carbon program. Aust. J. Agri. Resour. Econ., 62(3), 2018, 457-479.

52.ZHU, B., MA, S., XIE, R., CHEVALLIER, J., WEI, Y. M., Hilbert spectra and empirical mode decomposition: A multiscale event analysis method to detect the impact of economic crises on the European carbon market. Comput. Econ., 52(1), 2018, 105-121.

53.COMAN, G., BURCIU, M.S., BAROIU, N., Vehicles Emissions Under Different Driving Conditions in Urban Areas, Rev. Chim., 70(2), 2019, 438-441.

54.ZHU, B., ZHANG, M., HUANG, L., WANG, P., SU, B., WEI, Y. M., Exploring the effect of carbon trading mechanism on China's green development efficiency: A novel integrated approach. Energy. Econ., 85, 2020, 104601.

55.YU, D., ZHU, H., HAN, W., HOLBURN, D., Dynamic multi agent-based management and load frequency control of PV/Fuel cell/wind turbine/CHP in autonomous microgrid system. Energy, 173, 2019, 554-568.

56.LEI, Z., YANG, J., HUIBIN, H., CHAO, Y., MIN, L., LINTIAN, M., Preparation of soybean oil factory sludge catalyst by plasma and the kinetics of selective catalytic oxidation denitrification reaction. J. clean. Prod., 217, 2019, 317-323.

57.LEI, Z., JIHAO, C., ZHANG, L., HUIBIN, H., YUSU, W., YONGHUI, L., Preparation of soybean oil factory sludge catalyst and its application in selective catalytic oxidation denitration process. $J$. clean. Prod., 225, 2019, 220-226.

58.CAO, L., TU, C., HU, P., LIU, S., Influence of solid particle erosion (SPE) on safety and economy of steam turbines. Appl. Therm. Eng., 150, 2019, 552-563.

59.QING-XIN, Z., Air trajectory clustering based on atmospheric transport influence the formation of acid rain in Dandong City. China. Environ. Monitor., 29(1), 2013, 56-60.

60.YU, S., TING, H., WEN-YAO, P., Analysis of external source of acid rain in Dalian. J. Meteor. Environ., 30(6), 2014, 115-119.

61.SHI, M., QING-XIN, Z., YU, N., ZONG-JIAO, C., Analysis on the form of acid rain in Dalian based on air trajectory clustering. Environ. Sci. Technol., 34(12), 2011, 236- 241.

62.TIAN, X., SONG, Z., WANG, J., Study on the propagation law of tunnel blasting vibration in stratum and blasting vibration reduction technology. Soil. Dynamic. Earth. Eng., 126, 2019, 105813.

63.CHEN, H., FAN, D., HUANG, J., HUANG, W., ZHANG, G., HUANG, L., Finite Element Analysis Model on Ultrasonic Phased Array Technique for Material Defect Time of Flight Diffraction Detection. Sci. Adv. Mater., 12(5), 2020, 665-675. 
64.ZENG, L., CHEN, G., CHEN, H., Comparative Study on Flow-Accelerated Corrosion and Erosion-Corrosion at a $90^{\circ}$ Carbon Steel Bend. Materials, 13(7), 2020, 1780-1795.

65.LIU, Z., FENG, J., WANG, J., Effects of the sharing economy on sequential innovation products. Complexity, 2019, 1-18.

66.WANG, M., ZHANG, D. Q., CHENG, Y. N., TAN, S. K., Assessing performance of porous pavements and bioretention cells for stormwater management in response to probable climatic changes. Journal of Environmental Management, 243, 2019, 157-167.

67.ZHANG, Y. L., HUANG, P., Influence of mine shallow roadway on airflow temperature. Arab. J. Geosci., 13(1), 2020, 6.

68.NAFI, H., EZZAT, H., Intensification of Rain-Fed Peanut Production in Sudan. Ccamlr Sci., 26(1), 2019, 64-70.

$\overline{\text { Manuscript received: } 17.03 .2020}$ 